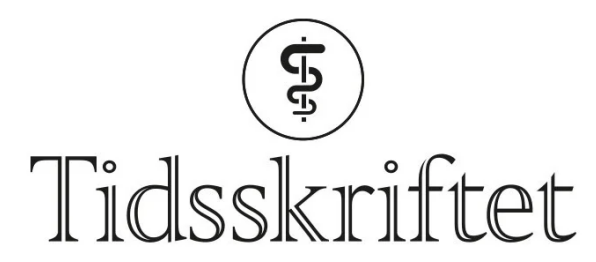

DEN NORSKE LEGEFORENING

\title{
Covid-19: Simuleringsmodeller ved epidemier
}

KRONIKK

\section{IVAR SØNBØ KRISTIANSEN}

i.s.kristiansen@medisin.uio.no

Ivar Sønbø Kristiansen er professor emeritus ved Universitetet i Oslo og adjungert professor ved Institut for Sundhedstjenesteforskning, Syddansk Universitet, Odense, med økonomisk evaluering og modellering som forskningsområde.

Forfatteren har fylt ut ICMJE-skjemaet og oppgir ingen interessekonflikter.

\section{EMILY ANNIKA BURGER}

Emily Annika Burger er forsker på modellering av screening og vaksinering ved humant papillomavirus-relatert sykdom ved Avdeling for helseledelse og helseøkonomi, Universitetet i Oslo og Harvard T.H. Chan School of Public Health.

Forfatteren har fylt ut ICMJE-skjemaet og oppgir ingen interessekonflikter.

\section{BIRGITTE FREIESLEBEN DE BLASIO}

Birgitte Freiesleben De Blasio er avdelingsdirektør ved Avdeling for metodeutvikling og analyse ved Folkehelseinstituttet og professor ved avdeling for biostatistikk, Universitetet i Oslo. Hun leder Folkehelseinstituttets forskergruppe for infeksjonsmodellering.

Forfatteren har fylt ut ICMJE-skjemaet og oppgir følgende interessekonflikter: Hun leder Folkehelseinstituttets forskergruppe for modellering av koronaviruspandemien som understøtter myndighetenes beslutninger.

\section{Intet menneske har hjernekapasitet til å tenke gjennom alle utfall ved en epidemi. En simuleringsmodell kan klare å holde orden på mange individer og faktorer som påvirker smitteforløpet. Men den kan aldri bli helt som virkeligheten.}

Helsetjenesten trenger svar på en rekke spørsmål når epidemier truer. Hvor mange kan bli smittet? Hvor mange vil trenge behandling i intensivavdeling? Hvor mange vil dø? Bør vi stenge skoler? Bør alle som kan, holde seg borte fra jobb? Hvem bør testes for smitte? Hvem bør settes i karantene? Hvordan kan en vaksine påvirke epidemiforløpet? Denne type spørsmål kan man ikke få svar på ved å lete etter randomiserte studier eller registerstudier hvis man som nå står overfor et nytt virus med ukjente egenskaper. I økende grad brukes statistisk modellering, såkalte infeksjonsmodeller, nasjonalt og globalt for å forstå og håndtere epidemier og utfordringer knyttet til infeksjonsutbrudd (1).

\section{Modellering av infeksjoner}


Epidemimodeller er en variant av infeksjonsmodeller og tar utgangspunkt i teori om infeksjoner og kunnskap om tidligere epidemier. Slike modeller simulerer sykdomsspredning fra person til person ved hjelp av computermodeller eller matematiske ligningssystemer (figur 1). Utgangspunktet er at én person kan smitte én eller flere andre. Dette tallfestes som det basale reproduksjonstall, $\mathrm{R}_{\mathrm{O}}$. $\mathrm{R}_{\mathrm{O}}$ er definert som det gjennomsnittlige antallet nye tilfeller generert av ett infisert individ $i$ en fullstendig mottagelig populasjon. $\mathrm{R}_{\mathrm{O}} \varnothing \mathrm{ker}$ med antall personer den smittede har kontakt med, sannsynligheten for smitteoverføring ved hver kontakt og varigheten av smittbarheten hos den infiserte. Under svineinfluensaepidemien (H1N1pdmog) ble $\mathrm{R}_{\mathrm{o}}$ beregnet til å være 1,35 (2). $R_{0}$ er antatt å være 5-7 for kopper og 16-18 for meslinger (3). Tidlig $i$ en epidemi når andelen mottagelige i populasjonen er høy, øker antall infiserte eksponentielt (figur 2).

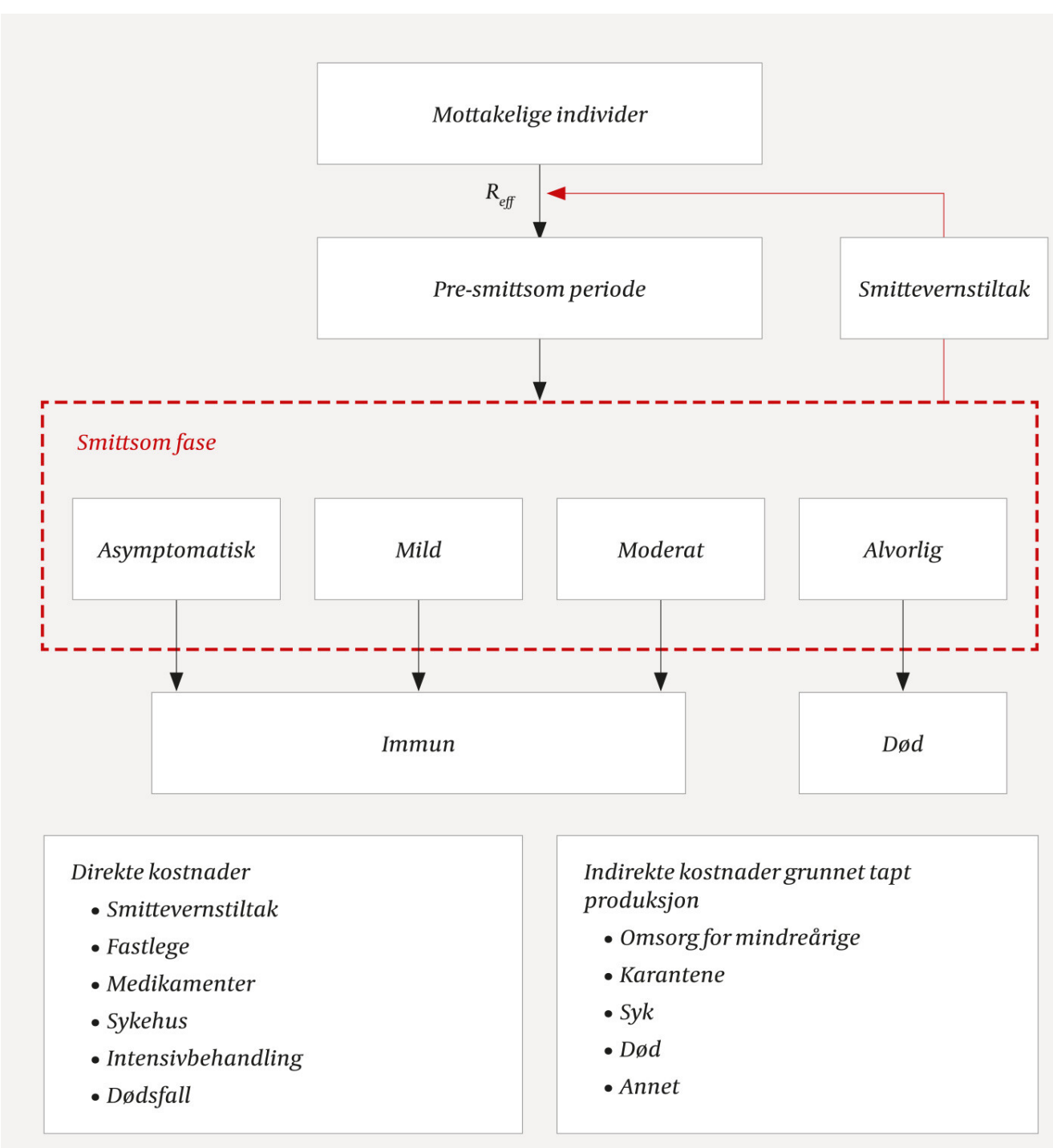

Figur 1 Skjematisk oversikt over en enkel infeksjonsmodell. Individer starter som mottagelige med en viss risiko for å bli smittet ut fra det effektive reproduksjonstallet (Reff). De smittede kan være asymptomatiske eller symptomatiske, dernest blir alle immune eller dør. Samfunnets kostnader kan deles i direkte kostnader og indirekte kostnader (produksjonstap). 


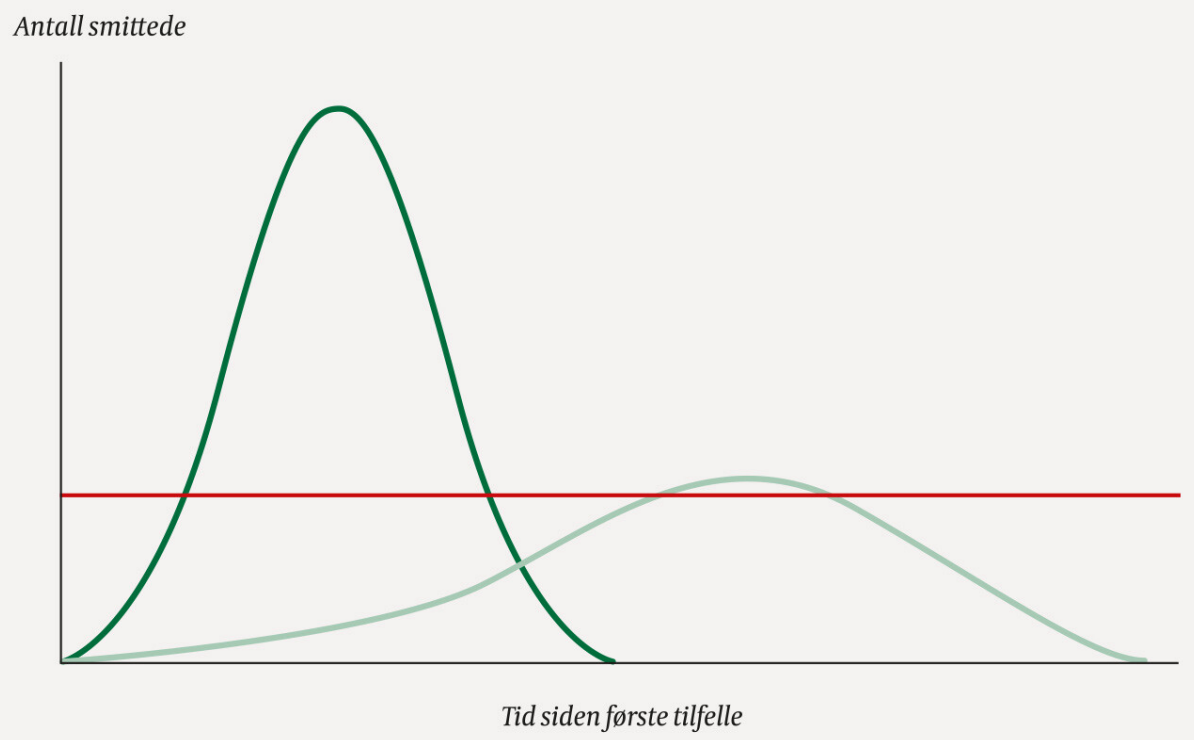

Figur 2 Antall infiserte med og uten samfunnstiltak under en epidemi. Etter hvert som andelen mottagelige synker i befolkningen, faller det effektive reproduksjonstallet $\mathrm{R}_{\mathrm{eff}}$, der $\mathrm{R}_{\mathrm{eff}}$ er $\mathrm{R}_{\mathrm{o}}$ multiplisert med andel mottagelige (figur 2 ). En

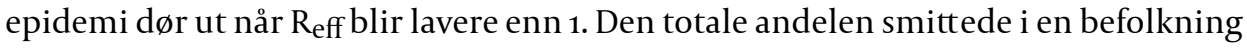
(attackrate) blir høyere desto høyere det basale reproduksjonstallet er. Når $\mathrm{R}_{0}$ er over 3, blir mer enn $90 \%$ smittet, med mindre effektive tiltak reduserer smitteoverføringen. Informasjon om det basale reproduksjonstallet er viktig tidlig i den første fasen av en epidemi. Dette tallet forteller beslutningstagere hvor omfattende tiltak som er nødvendige for å kontrollere epidemien.

De enkleste epidemimodellene, såkalte SIR-modeller, tar utgangspunkt i at en populasjon kan deles i tre grupper: mottagelige (susceptible), infiserte (infected) og immune eller døde (recovered). Basert på det basale reproduksjonstallet og en rekke andre parametere kan man beregne antall asymptomatiske og kliniske tilfeller, antall sykehusinnlagte og døde. Et sentralt element er data om hvor mye gruppene skolebarn, yrkesaktive og eldre mennesker omgås hverandre og innad i gruppene. Slike data er nødvendige for å simulere smittespredningen og fås fra sosiale kontaktstudier. Nasjonale beredskapsplaner bør så vidt mulig baseres på lokale data fordi ulikheter i kontaktmønstre kan gi stor variasjon $\mathrm{i}$ epidemiers utvikling.

Enklere modeller, som for eksempel kreftmodeller, antar at betydningen av risikofaktorer er konstant over tid og sted og at sykdom hos ett individ ikke påvirker risikoen for sykdom hos andre. Ved infeksjoner endres imidlertid sannsynligheten for hendelser over tid og ut fra sted. Ett individ eller en gruppe individer kan påvirke andres risiko for sykdom. Infeksjonsmodeller kalles derfor dynamiske. Dette gjør denne type modellutvikling langt mer krevende.

\section{«For alle simuleringsmodeller gjelder regelen om at resultatene ikke er mer pålitelige enn tallgrunnlaget man putter inn»}

Sensitivitetsanalyser er viktige ved alle modellstudier. Da gjennomfører man mange simuleringer mens man endrer ulike parametere i modellen, for eksempel $\mathrm{R}_{0}$ eller dødsrisiko blant infiserte. Slik får man informasjon om hvor mye den usikkerheten i dataene man legger inn i modellen, påvirker de simulerte resultatene. Det kan også være aktuelt å unders $\varnothing$ ke om endringer i modellens logiske struktur påvirker resultatene. 
Etter at en infeksjonsmodell er utviklet, må den valideres. Man må kontrollere at den ikke inneholder regnefeil og at dens prediksjoner er i tråd med virkeligheten. Etter hvert som nye data blir tilgjengelige, blir modeller oppdatert og revalidert for å sikre at de er i samsvar med status, så langt man til enhver tid kjenner denne. Under en epidemi der man iverksetter tiltak fortløpende, må man hele tiden følge utviklingen i smittespredning og det effektive reproduksjonstallet for å vurdere effekten av tiltak og behovet for nye intervensjoner.

\section{Prediksjon og vurdering av tiltak}

En infeksjonsmodell kan ha mange anvendelser. Under en epidemi trenger man kunnskap om sannsynlige konsekvenser av utbruddet. Helsemyndighetene har behov for å vite hvordan antallet smittede kan tenkes å utvikle seg over tid, hvor mange som kan komme til å trenge sykehusinnleggelse eller respiratorbehandling og hvor mange som kan $\mathrm{d} ø$. Ved et typisk forløp av en epidemi ser man først en periode med eksponentiell vekst i antallet

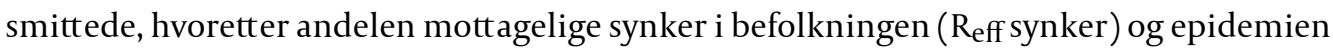
dør ut (figur 2). Man kan også simulere effekten av intervensjoner som karantene, skolestengning, legemiddelbehandling og vaksine der slike er aktuelle (figur 2).

Ved å koble epidemimodeller med helseøkonomiske modeller får man et rammeverk som kan være til hjelp ved helsepolitiske beslutninger. På den måten vil man for eksempel kunne si noe om behov for sykehussenger, legemidler, intensivplasser og kostnadseffektivitet av tiltak.

\section{Skolestengning og sykmeldinger}

Yiting Xue og medarbeidere studerte kostnader og nytte ved skolestengning under influensapandemier i Norge (4). De antok at infiserte kunne forbli asymptomatiske eller utvikle mild til moderat sykdom, alvorlig sykdom med sykehusinnleggelse eller $\mathrm{d} \emptyset$ av influensa. Utfallene ble «oversatt» til tap av kvalitetsjusterte leveår. Redusert sykelighet eller dødelighet av tiltak ble således målt i kvalitetsjusterte leveår. Modellen fanget opp unngåtte kostnader i helsetjenesten ved skolestengning samt tapt produksjon i samfunnet fordi mindreårige måtte ha tilsyn hjemme. Den fanget også opp verdien av tapt undervisning, men interessant nok finnes det nesten ikke data om hva elevene taper ved kortvarig skolefravær. Resultatene tydet på at det er lønnsomt å stenge skoler for elever som ikke trenger tilsyn hjemme under stengningen. For de yngre elevene avhenger resultatene av hvor alvorlig epidemien er og om man tar hensyn til samfunnets produksjonstap når barnas foresatte må være borte fra arbeid.

En beslektet problemstilling er retningslinjer for sykmelding ved mistanke om influensa (5). Basert på en studie av sykefravær ved influensalignende symptomer estimerte Edwards og medarbeidere kostnader og nytte (므). De varierte andelen som holdt seg hjemme fra arbeid ved symptomer og varigheten av fraværet. Analysene tydet på at rask sykmelding av en høy andel ansatte vil være samfunnsøkonomisk lønnsomt, særlig ved høy sykelighet og dødelighet. Noe overraskende var sykmelding mest kostnadseffektivt ved epidemier med lavt basalt reproduksjonstall.

Tiltak som reiseforbud, isolering av smittede og skolestengning ved en epidemi har til hensikt å redusere smitteoverføringen slik at det effektive reproduksjonstallet blir mindre enn det basale reproduksjonstallet. Influensaanalysene over illustrerer et viktig aspekt ved slike tiltak: Epidemien forsinkes i tid, og det maksimale antallet syke på et enkelt tidspunkt blir lavere (figur 2). De mest effektive tiltakene synes å kunne utsette influensaepidemiens maksimalbelastning med 50-6o dager. Tiltakene gir altså helsetjenesten mer tid til å forberede seg på epidemien samtidig som dens toppbelastning blir mindre.

\section{Covid-19-modellering}


Norge har flere forskningsmiljøer med kompetanse innen modellering av infeksjonssykdommer, blant annet ved Universitetet i Oslo og Folkehelseinstituttet. Forskerne herfra har publisert analyser om meticillinresistente gule stafylokokker (MRSA), herpes zoster, rotavirus, hepatitt C, humant papillomavirus og influensa.

Folkehelseinstituttet gjennomførte i 2017 en studie der 4300 tilfeldig utvalgte nordmenn ble bedt om å fylle ut en dagbok over alle kontakter de hadde i løpet av én enkelt dag (7.). På denne måten har man fått data om sosiale nettverk og muligheten for å spre smitte i det norske samfunnet.

Folkehelseinstituttet har de seneste årene samarbeidet med Telenor og Universitetet i Oslo om bruk av mobiltelefondata i infeksjonsmodeller. Fra februar 2020 har de sammen med Norsk Regnesentral videreutviklet en modell som kan predikere spredning av covid-19 i Norge på kommunenivå den neste uken og måneden. I modellen brukes Telenors mobiltelefondata fra norske abonnenter samt daglig oppdaterte epidemiologiske data. Det kjøres mange simuleringer for å estimere usikkerhet, og modellen tilpasses nye data etter hvert som de blir tilgjengelige. Sanntidsdata er altså en del av epidemiberedskapen, men dessverre er det stadig vanskelig å raskt hente ut og koble registerdata om blant annet infeksjoner ( $\underline{8})$.

Tall fra Folkehelseinstituttet tilsa 9. mars at Norge kunne få ca. 22 ooo sykehusinnleggelser pga. covid-19-infeksjoner, hvorav 5500 i intensivavdeling (9.). Ifølge beregningene ville sykehusene på det verste ha 1700 innlagte samtidig, hvorav 6oo i intensivavdeling. Slike tall er knyttet til et planscenario, hvor man vurderer konsekvenser under gitte antagelser. Antagelsene må tolkes med varsomhet fordi kunnskap om viruset og dets spredning fortsatt var, og er, begrenset. Folkehelseinstituttets modeller oppdateres etter hvert som ny informasjon kommer inn. Modellen gjør det også mulig å evaluere effekten av de tiltakene som settes inn.

Selv om covid-19-epidemien har pågått fra desember 2019, er det i skrivende stund (17. mars 2020) fortsatt usikkert hva det basale reproduksjonstallet $\left(R_{0}\right)$ er, selv om man tror tallet er større enn ved sesonginfluensa. I en nylig publisert studie ble $\mathrm{R}_{\mathrm{o}}$ estimert til 2,35 i Wuhan 16. januar, en uke før det ble innført restriksjoner. Det effektive reproduksjonstallet (Reff) var 1,05 etter at tiltak var iverksatt (10 $)$. Andelen smittede som dør, er også usikker. Antall smittede blir lett underestimert fordi noen smittede har få eller ingen symptomer og på grunn av manglende smitteoppsporing eller manglende testkapasitet. Testkriteriene kan variere mellom land, og noen land mangler utstyr for testing. Dette betyr samlet sett at antall smittede underestimeres, og andel døde av covid-19 blir tilsvarende overvurdert.

\section{Diskusjon}

For alle simuleringsmodeller gjelder regelen om at resultatene ikke er mer pålitelige enn tallgrunnlaget man putter inn (garbage in - garbage out). En viktig begrensning ved infeksjonsmodellering er nettopp usikkerhet knyttet til datagrunnlaget. Tross usikkerhet kan modeller gi oss nyttig innsikt, blant annet om hvilken type data det er viktig å skaffe informasjon om. Da panikken rundt hiv rådet i Norge i 1980-årene, satte Hein Stigum og medarbeidere opp et sett differensialligninger basert på antagelser om seksualadferd og hivvirusets egenskaper $(\underline{11}, \underline{12})$. De konkluderte med at Norge ikke hadde noen grunn til å frykte en omfattende hivepidemi. Noen oppfattet den gang disse resultatene som kontraintuitive, men tiden skulle vise at forutsetningene og antagelsene i hovedsak var korrekte.

En viktig innsikt fra modellering av infeksjoner er at intet menneske har hjernekapasitet til å tenke igjennom alle utfall i en komplisert kjede av hendelser som man ser ved en epidemi. Et ligningssett eller et computerprogram kan klare å holde orden på mange 
individer og faktorer som påvirker smitteforløpene. Likevel kan ingen simuleringsmodell bli helt som virkeligheten - den er og blir en modell. Vi slutter oss derfor til statistikeren George Box som slår fast at «all models are wrong, but some are useful» (13).

\section{LITTERATUR}

1. Heesterbeek H, Anderson RM, Andreasen V et al. Modeling infectious disease dynamics in the complex landscape of global health. Science 2015;347: aaa4339. [PubMed][CrossRef]

2. Blasio BF, Iversen BG, Tomba GS. Effect of vaccines and antivirals during the major $2009 \mathrm{~A}\left(\mathrm{H}_{1} \mathrm{~N}_{1}\right)$ pandemic wave in Norway-and the influence of vaccination timing. PLoS One 2012; 7: ezoo18. [PubMed][CrossRef]

3. Centers for Disease Control and Prevention. Smallpox: Disease, Prevention, and Intervention. Slides 16-17. https://stacks.cdc.gov/view/cdc/27929 Lest 7.3.2020.

4. Xue Y, Kristiansen IS, de Blasio BF. Dynamic modelling of costs and health consequences of school closure during an influenza pandemic. BMC Public Health 2012; 12: 962. [PubMed][CrossRef]

5. Edwards $\mathrm{CH}$, Tomba GS, Sonbo Kristiansen I et al. Evaluating costs and health consequences of sick leave strategies against pandemic and seasonal influenza in Norway using a dynamic model. BMJ Open 2019; 9: e027832. [PubMed][CrossRef]

6. de Blasio BF, Xue Y, Iversen B et al. Estimating influenza-related sick leave in Norway: was work absenteeism higher during the $2009 \mathrm{~A}\left(\mathrm{H}_{1} \mathrm{~N}_{1}\right)$ pandemic compared to seasonal epidemics? Euro Surveill 2012; 17: 20246. [PubMed]

7. Folkehelseinstituttet. Vaksinasjonsdekning og spredningspotensiale for smittsomme sykdommer i Norge - prosjektbeskrivelse. https://www.fhi.no/prosjekter/vaksinasjonsdekning-ogspredningspotensiale-prosjektbeskrivelse/ Lest 10.3.2020.

8. Time JK. Vitenskap i en unntakstilstand. Morgenbladet 4.3.2020. https://morgenbladet.no/aktuelt/2020/o3/vitenskap-i-en-unntakstilstand Lest 5.3.2020.

9. Kalveland J. Anslår 1 70o korona-innleggelser. Dagens Medisin 9.3.2020. https://www.dagensmedisin.no/artikler/2020/03/o9/anslar-1.70o-korona-innleggelser-paepidemitoppen/ Lest 16.3.2020.

10. Kucharski AJ, Russell TW, Diamond C et al. Early dynamics of transmission and control of COVID19: a mathematical modelling study. Lancet Infect Dis 2020 doi:10.1016/S1473-3099(20)30144-4. [PubMed][CrossRef]

11. Magnus P, Stigum H, Grønnesby JK et al. Spådommer for omfanget av heteroseksuelt betinget HIVinfeksjon i Norge i 1990-årene. Tidsskr Nor Lægeforen 1990; 110:3225-8. [PubMed]

12. Stigum H, Magnus P, Grønnesby JK et al. Nytten av simuleringsmodeller i forståelsen av HIVepidemien. Tidsskr Nor Lægeforen 1988; 108: 115-9. [PubMed]

13. Box GE. Science and statistics. J Am Stat Assoc 1976; 71: 791-9. [CrossRef]

Publisert: 18. mars 2020. Tidsskr Nor Legeforen. DOI: 10.4045/tidsskr.20.0225

(C) Tidsskrift for Den norske legeforening 2023. Lastet ned fra tidsskriftet.no 26. april 2023. 